\title{
Pengaruh Sikap Konsumen, Persepsi Harga Dan Persepsi Risiko Terhadap Keputusan Pembelian Kosmetik Berlabel Halal (Studi pada Konsumen Pengguna Kosmetik Berlabel Halal di Purwokerto)
}

\author{
Nadela Saktiana ${ }^{(1)}$ \\ Program Studi Manajemen S1 \\ Fakultas Ekonomi dan Bisnis Universitas Muhammadiyah Purwokerto ${ }^{1}$ \\ Email : ${ }^{1}$ nadelasaktiana212@gmail.com \\ Muchammad Agung Miftahuddin ${ }^{(2)}$ \\ Program Studi Manajemen S1 \\ Fakultas Ekonomi dan Bisnis Universitas Muhammadiyah Purwokerto ${ }^{2}$ \\ Email : ${ }^{2}$ amif_ump@yahoo.com
}

\begin{abstract}
ABSTRAK
Penelitian ini bertujuan untuk mengetahui pengaruh Sikap Konsumen, Persepsi Harga dan Persepsi Risiko Terhadap Keputusan Pembelian. Penelitian ini menggunakan metode penelitian kuantitatif dalam bentuk penelitian survey. Jumlah sampel yang digunakan sebanyak 110 responden yang di ambil menggunakan purposive sampling dengan kriteria yang telah disyaratkan. Berdasarkan uji simultan (F test) Sikap Konsumen, Persepsi Harga dan Persepsi Risiko secara simultan berpengaruh signifikan terhadap keputusan pembelian dengan variabilitas 49,4\%. Sedangkan uji parsial (t test) diperoleh Sikap Konsumen berpengaruh negatif signifikan terhadap keputusan pembelian, Persepsi Harga dan Persepsi Risiko masing-masing berpengaruh positif signifikan terhadap keputusan pembelian.

Kata kunci : Sikap Konsumen, Persepsi Harga, Persepsi Risiko dan Keputusan Pembelian.
\end{abstract}

\section{ABSTRACT}

This study aims to determine the effect of consumer attitudes, price perceptions and risk perceptions of purchasing decisions. This research uses quantitative research methods in the form of survey research. The number of samples used was 110 respondents who were taken using purposive sampling with the criteria that have been interpreted. Based on a simultaneous test (F test) of consumer attitudes, price perception and risk perception simultaneously have a significant effect on purchasing decisions with $49.4 \%$ variability. While the partial test ( $t$ test) obtained by the attitude of consumers has a significant negative effect on purchasing decisions. price perception and risk perception respectively have a significant positive effect on purchasing decisions.

Keywords: Consumer Attitude, Price Perception, Risk Perception and Purchasing Decisions.

\section{PENDAHULUAN}

Seiring perkembangan zaman kebutuhan manusia tidak hanya terbatas pada kebutuhan sandang pangan serta kebutuhan pokok saja. Dalam era modern ini kesehatan, kenyamanan dan kecantikan sudah menjadi kebutuhan bagi mereka, baik dari fisik maupun psikologis. Persaingan bisnis mengalami peningkatan yang begitu pesat. Seiring dengan meningkatnya persaingan bisnis banyak dampak positif yang ditimbulkan terhadap perkembangan dunia bisnis. Hal ini tentu saja mendorong perkembangan di sektor industri, baik itu berskala besar maupun kecil dengan bidang usaha yang beragam. Kementerian perindustrian (Kemenperin) memperkirakan sejumlah sektor industri akan mengalami pertumbuhan yang tinggi di tahun 2019. Menteri perindustrian menyatakan bahwa industri telah berperan penting, sehingga menjadi sektor andalan untuk mengakselerasi pertumbuhan 
ekonomi nasional. Capaian ini terbesar disumbangi oleh dari lima sektor manufaktur, yakni industri makanan dan minuman, industri tekstil dan pakaian, industri otomotif, industri kimia dan industri elektronika (m.liputan6.com).

Pesatnya perkembangan sektor industri memaksa pemasar untuk meningkatkan kualitas produk sehingga membuat para konsumen menjadi loyal terhadap produk mereka. Untuk menarik konsumen maka setiap pemasar harus kreatif dan inovatif dalam mengembangkan produknya sehingga mereka mempertahankan kepuasan konsumen. Hal ini didukung oleh menteri perindustrian Airlangga Hartarto yang mengemukakan bahwa inovasi dan kreativitas harus dikembangkan dalam memproduksi produk dalam negeri (m.antaranews.com). Karena sebelum melakukan keputusan pembelian konsumen akan memilih dan mengevaluasi suatu produk, jika konsumen merasa produk tersebut dapat memenuhi keinginan dan kebutuhannya pasti konsumen akan mengambil keputusan pembelian. Tidak hanya kreatif dan inovatif pemasar harus menjamin kualitas sehingga pada masanya menjadikan konsumen yang loyal. Semakin tinggi tingkat kepercayaan konsumen, semakin besar dampaknya terhadap keputusan pembelian konsumen, sehingga jika konsumen sudah percaya dan loyal terhadap suatu produk maka akan mempengaruhi konsumen untuk melakukan keputusan pembelian ulang terhadap produk perusahaan.

Di Indonesia industri kosmetik sangat menarik para investor, karena pertumbuhan kebutuhan konsumen akan kosmetik semakin banyak dan mencerminkan potensi pasar yang tinggi. Berdasarkan data dari kementerian perindustrian mencatat, pada tahun 2017 industri kosmetik nasional tumbuh mencapai 6,35\% dan pada tahun 2018 mengalami kenaikan sebanyak 7,36\%. Disisi lain pelaku usaha di dalam negeri bertambah sebanyak 153 perusahaan pada tahun 2017, sehingga total saat ini mencapai lebih dari 760 perusahaan. Dari total tersebut sebanyak 95\% industri kosmetik nasional merupakan sektor industri kecil dan menengah (IKM) dan sisanya 5\% merupakan industri skala besar. Industri kosmetik tidak bisa terpisahkan dengan sektor kreatif atau lifestyle, dan melibatkan keterkaitan antara industri kosmetik menengah (IKM) dengan industri besar (kemenperin.go.id). Meningkatnya pertumbuhan konsumen dan permintaan pasar terhadap produk kosmetik di dalam negeri, didorong oleh semakin kuatnya tren penggunaan kosmetik oleh masyarakat dan menjadi kebutuhan primer bagi kaum wanita.

Berdasarkan data badan pengawas obat dan makanan (BPOM) produk kosmetik yang sudah memiliki izin edar dalam negeri hanya mampu memasok 150.000 produk dari kebutuhan kosmetik yang ada (m.antaranews.com). Sehingga kelebihan permintaan tersebut dipenuhi oleh produk kosmetik impor, yang menawarkan produk dengan harga yang lebih murah dan dikemas secara baik. Hal ini berdampak munculnya kosmetik palsu dan mengandung zat kimia berbahaya beredar dipasaran, sehingga memunculkan kekhawatiran pada konsumen akan produk kosmetik yang digunakan. Untuk itu Badan Pengawas Obat dan Makanan (BPOM) mengajak perusahaan kosmetik agar menghasilkan kosmetik yang tidak merusak kulit. Berdasarkan data LPPOM MUI pada tahun 2018, terdapat 41 perusahaan dengan total 2.115 produk bersertifikat halal (m.cnnindonesia.com). Dalam hal ini, LPPOM MUI terus mengakomodir permintaan para konsumen yang ingin mencari tahu kosmetik apa saja yang bersertifikat halal. Berikut 10 teratas produk label halal berdasarkan rangkuman dari situs resmi LPPOM MUI diantaranya ada Wardah, Sariayu, By Lizzie Parra (BLP Beauty), Zoya Cosmetics, Esqa, Amara Halal Cosmetics, Safi, L'Oreal, ForestSecret dan Olive Natural Skincare (m.kumparan.com). 
Konsumen dari produk kosmetik sangat beragam, salah satunya ialah muslimah. Populasi muslimah berhijab di Indonesia kini mencapai 61\%. Dari data tersebut sudah banyak muslimah yang berhijrah, sehingga meningkatkan kesadaran masyarakat akan mengkonsumsi dan menggunakan produk halal, termasuk produk kosmetik. Terlebih dipahami bahwa tidak sah shalat seseorang jika ada bahan baku non halal yang dipakai diwajah dan tubuhnya. Sebagai konsumen, mereka aktif mencari berbagai cara untuk menampilkan kecantikan yang sesuai dengan fitrah, yaitu kecantikan yang murni dan modis, sesuai dengan syariat islam dan tidak mencolok atau berlebihan. Hal ini akan berdampak semakin tingginya kepedulian konsumen terhadap produk berlabel halal pada produk yang dibelinya (www.swa.co.id).

Halal diperuntukan bagi segala sesuatu yang bersifat baik dan bersih bagi manusia, sebagaimana Allah telah menegaskan dalam QS. Al-Maidah ayat 3. Ayat ini menjelaskan bahwa "memakan" bukan hanya diartikan sebagai memakan lewat mulut, tapi memakan tersebut diartikan sebagai mengkonsumsi dalam artian menggunakan olahan babi untuk berbagai keperluan termasuk kosmetik. Kosmetik yang tidak halal berarti dalam proses pembuatannya serta bahan yang digunakan mengandung zat-zat yang diharamkan secara Islam (Sari dkk, 2018).

Secara bahasa, kata "Halal" berasal dari bahasa Arab yang sudah diserap menjadi bahasa Indonesia. Halal berasal dari kata "halla" yang berarti diizinkan, dibolehkan atau tidak dilarang dan lawan kata dari haram. Ahmad Al-Syarbasi menyebutkan, halal adalah segala sesuatu yang tidak dihukum bagi pelakunya atas perlakuannya, maka halal adalah segala sesuatu yang dibolehkan syariat atas perbuatannya. Menurut Lembaga Pengkajian Pangan, Obat dan Kosmetik Majelis Ulama Indonesia (LPPOM MUI) yang dimaksud dengan produk halal adalah suatu produk sesuai dengan syarikat Islam dan menjadi syarat pencantuman label halal dalam setiap produk makanan, minuman, obat-obatan dan Kosmetika (halalmuibali.or.id).

Produk halal juga tidak boleh mengandung unsur atau barang haram yang dilarang untuk dikonsumsi umat Islam baik yang menyangkut bahan baku, bahan tambahan dan bahan pembantu lainnya. Bahan produksi yang diolah melalui proses rekayasa genetika dan radiasi yang pengolahannya dilakukan sesuai dengan syariat Islam yang merupakan persyaratan dari label halal. Label halal diberikan kepada sebuah produk juga karena produk tersebut dan kandungan didalamnya memberikan lebih banyak manfaat dari pada mudharatnya.

Menurut Kotler dan Keller (2009) keputusan pembelian secara penuh merupakan suatu proses yang berasal dari semua pengalaman mereka dalam pembelajaran, memilih, menggunakan dan bahkan menyingkirkan suatu produk. Dalam tahap evaluasi, konsumen membentuk preferensi antar merek dalam kumpulan pilihan. Konsumen mungkin juga membentuk maksud untuk membeli merek yang paling disukai. Proses pengambilan keputusan sangat dipengaruhi oleh perilaku konsumen. Proses tersebut sebenarnya merupakan proses pemecahan masalah dalam rangka memenuhi keinginan atau kebutuhan konsumen.

Tidak hanya berlabel halal para pemasar atau perusahaan harus melihat lebih jauh bagaimana macam faktor yang mempengaruhi konsumen dalam melakukan keputusan pembelian. Dengan memahami pola keputusan pembelian, perusahaan dapat memenangkan hati pelanggan dan menjadikan pelanggan setia terhadap perusahaan. Untuk meningkatkan keputusan pembelian produk kosmetik berlabel halal ada beberapa pertimbangan faktor yang 
terbukti signifikan. Hal ini sesuai dengan hasil penelitian dari (Arifin dan Khasanah, 2017) dan (Rahmadi dan Malik, 2016).

Salah satu faktor yang mempengaruhi keputusan pembelian kosmetik berlabel halal adalah sikap konsumen. Menurut Sangadji dan Sopiah (2013) Sikap konsumen adalah tanggapan perasaan konsumen yang bisa berupa perasaan suka atau tidak suka terhadap objek tertentu, misalnya bagaimana sikap konsumen terhadap kinerja produk, bagaimana sikap konsumen terhadap terhadap merek perusahaan, bagaimana sikap konsumen terhadap harga produk, bagaimana sikap konsumen terhadap iklan produk perusahaan yang ditayangkan di TV, dan sebagainya. Seperti halnya dengan penelitian yang dilakukan oleh Arifin dan Khasanah (2017) yang memberikan hasil bahwa sikap konsumen berpengaruh posif signifikan terhadap keputusan pembelian.

Selain sikap konsumen yang mempengaruhi keputusan pembelian kosmetik berlabel halal, ada faktor lain yang mempengaruhi yaitu persepsi harga. Persepsi harga dapat menjadi bahan pertimbangan konsumen untuk mempengaruhi keputusan pembelian suatu produk. Bagaimana konsumen memandang harga tertentu tinggi, rendah, wajar mempunyai pengaruh yang kuat terhadap keputusan pembelian. Sehingga persepsi harga berpengaruh signifikan terhadap keputusan pembelian kosmetik berlabel halal. Seperti penelitian yang dilakukan oleh Arifin dan Khasanah (2017) yang memberikan hasil bahwa persepsi harga berpengaruh positif signifikan terhadap keputusan pembelian.

Ketika melakukan suatu pembelian atau sebuah keputusan untuk memilih suatu produk dan memberikan pengaruh terhadap keputusan pembelian kosmetik berlabel halal ada faktor lain selain sikap konsumen dan persepsi harga yaitu persepsi risiko. Persepsi risiko menurut (Shiffman dan Kanuk, 2008) dalam (Rahmadi dan Malik, 2016) mendefinisikan persepsi risiko adalah ketidakpastian yang dihadapi para konsumen jika mereka tidak dapat meramalkan konsekuensi keputusan pembelian mereka. Ketika persepsi risiko tinggi, konsumen mempunyai pilihan apakah akan menghindari pembelian dan penggunaan atau meminimumkan risiko melalui pencarian evaluasi alternatif pra-pembelian dalam tahap pengambilan keputusan.

Hal ini menghasilkan pengambilan keputusan yang kompleks. Konsumen melakukan beberapa kegiatan untuk mengurangi ketidakpastian dan konsekuensi negatif dari risiko seperti menghindari keputusan, mengumpulkan informasi dari teman dan meningkatkan kecenderungan terhadap merek dan jaminannya. Sehingga dapat ditarik kesimpulan bahwa persepsi risiko berpengaruh signifikan terhadap keputusan pembelian. Seperti penelitian dari Anandita dan Saputra (2015) yang menunjukan hasil bahwa persepsi risiko berpengaruh signifikan terhadap keputusan pembelian. Lain halnya dengan penelitian dari Rahmadi dan Malik (2016) yang memberikan hasil bahwa persepsi risiko tidak berpengaruh terhadap keputusan pembelian.

Penelitian ini merupakan pengembangan dari penelitian sebelumnya yang dilakukan oleh (Arifin dan Khasanah, 2017) yang mengindikasikan sikap konsumen dan persepsi harga berpengaruh positif signifikan terhadap keputusan pembelian. Peneliti menambah 1 variabel bebas persepsi risiko diambil dari penelitian yang dilakukan oleh (Rahmadi dan Malik, 2015). Alasan peneliti menghilangkan variabel kualitas dan kepercayaan pada penelitian yang dilakukan oleh (Arifin dan Khasanah, 2017) dan (Rahmadi dan Malik, 2015) karena dalam penelitian sebelumnya variabel bebas tersebut mengindikasikan hasil yang konsisten. Perbedaan penelitian ini dengan penelitian sebelumnya adalah subjeknya. Maka berdasarkan latar belakang masalah diatas, peneliti tertarik untuk menganalisis " Pengaruh Sikap 


\section{Konsumen, Persepsi Harga dan Persepsi Risiko Terhadap Keputusan Pembelian Kosmetik Berlebel Halal". \\ TUJUAN PENELITIAN}

Tujuan penelitian ini adalah untuk mengetahui :

a. Menganalisis pengaruh sikap konsumen, persepsi harga dan persepsi risiko secara bersama-sama terhadap keputusan pembelian kosmetik berlabel halal.

b. Menganalisis pengaruh sikap konsumen terhadap keputusan pembelian kosmetik berlabel halal.

c. Menganalisis pengaruh persepsi harga terhadap keputusan pembelian kosmetik berlabel halal.

d. Menganalisis pengaruh persepsi risiko terhadap keputusan pembelian kosmetik berlebel halal.

\section{KERANGKA PEMIKIRAN}

Kerangka pemikiran dari penelitian ini adalah sebagai berikut :

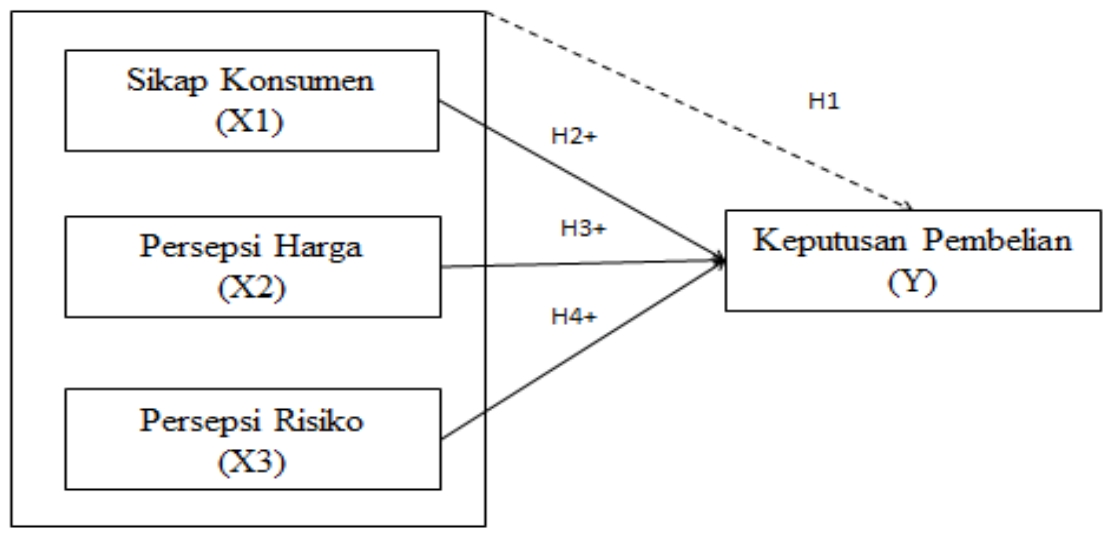

Gambar 1. Kerangka pemikiran

\section{DEFINISI OPERASIONAL}

1. Sikap konsumen adalah tanggapan perasaan konsumen yang bisa berupa perasaan suka atau tidak suka terhadap objek tertentu, misalnya bagaimana sikap konsumen terhadap kinerja produk, bagaimana sikap konsumen terhadap harga produk (Sangadji dan Sopiah, 2013).

Adapun indikator sikap konsumen dalam penelitian ini merujuk dari pendapat Sangadji dan Sopiah (2013) yang meliputi Kognitif, Afektif dan Konatif.

2. Persepsi harga adalah cara pandang konsumen dalam menilai apakah sebuah produk mempunyai harga yang wajar, mahal atau murah, yang akan menentukan nilai suatu produk (Schifmann dan Kanuk ,2007) dalam (Budiyanto, 2018).

Adapun indikator persepsi harga dalam penelitian ini menurut Samosir dan Prayoga (2015) yang meliputi :

a. Keterjangkauan harga

b. Adanya persaingan harga terhadap terhadap produk sejenis 

c. Asumsi harga konsumen
d. Harga sebagai indikator kualitas
e. Periode harga yang ditetapkan

3. Persepsi risiko (perceived risk) adalah ketidakpastian yang dihadapi para konsumen jika mereka tidak dapat meramalkan konsekuensi keputusan pembelian mereka (Shifman dan Kanuk, 2008) dalam (Rahmadi dan Malik, 2016).

Adapun Indikator persepsi risiko dalam penelitian ini menurut Nitisusastro (2012) dalam Rahmadi dan Malik (2016) adalah sebagai berikut :
a. Risiko keuangan (financial risk)
b. Risiko sosial (social risk)
c. Risiko fungsional (performance risk)
d. Risiko waktu (time risk)
e. Risiko fisik (phsycal risk)
f. Risiko Psikologis (psychological risk)

4. Keputusan pembelian secara penuh merupakan suatu proses yang berasal dari semua pengalaman mereka dalam pembelajaran, memilih, menggunakan dan bahkan menyingkirkan suatu produk. Dalam tahap evaluasi, konsumen membentuk preferensi antar merek dalam kumpulan pilihan (Kotler dan Keller, 2009).

Adapun indikator keputusan pembelian dalam penelitian ini menurut Kotler dan Keller (2009) yang meliputi :
a. Pengenalan masalah
b. Pencarian informasi
c. Evaluasi alternatif
d. Keputusan pembelian
e. Perilaku pasca pembelian

\section{METODE PENELITIAN}

Penelitian ini menggunakan metode penelitian kuantitatif. Menurut Sugiyono (2016) metode kuantitatif dinamakan metode tradisional, karena metode ini sudah cukup lama digunakan sehingga sudah mentradisi sebagai metode untuk penelitian. Metode ini disebut sebagai metode positivistik karena berlandaskan pada filsafat positivisme. Metode ini sebagai metode ilmiah/scientific karena telah memenuhi kaidah-kaidah ilmiah yaitu konkrit/empiris, objektif, terukur, rasional dan sistematis. Dalam penelitian ini, teknik pengumpulan data menggunakan kuesioner.

\section{Populasi dan Sampel}

Populasi adalah keseluruhan jumlah yang terdiri atas objek atau subjek yang mempunyai karakteristik dan kualitas tertentu yang ditetapkan oleh peneliti untuk diteliti dan kemudian ditarik kesimpulan. (Sujarweni, 2015). Populasi dalam penelitian ini adalah konsumen yang membeli dan menggunakan kosmetik berlabel halal. Konsumen wanita yang memakai kosmetik berlabel halal di Purwokerto. Sampel dalam penelitian ini sebanyak 110 responden. 


\section{KARAKTERISTIK RESPONDEN}

Karakteristik dari 110 responden yang berpartisipasi dalam penelitian ini dapat dideskripsikan berdasarkan usia, produk yang digunakan, pekerjaan dan pendapatan perbulan.

Tabel 1. Deskripsi Responden

\begin{tabular}{|c|c|c|c|c|}
\hline No & \multicolumn{2}{|c|}{ Uraian Responden } & $\begin{array}{c}\text { Jumlah } \\
\text { Responden }\end{array}$ & $\begin{array}{c}\text { Persentase } \\
(\%)\end{array}$ \\
\hline \multirow{3}{*}{1} & \multirow{3}{*}{ Usia } & $<20$ tahun & 22 & $20 \%$ \\
\hline & & 20-30 tahun & 84 & $76,4 \%$ \\
\hline & & $>30$ tahun & 4 & $3,6 \%$ \\
\hline \multicolumn{3}{|c|}{ Jumlah } & 110 & $100 \%$ \\
\hline \multirow{9}{*}{2} & \multirow{9}{*}{ Nama Produk } & Safi & 9 & $8,2 \%$ \\
\hline & & Wardah & 79 & $71,8 \%$ \\
\hline & & Make Over & 2 & $1,8 \%$ \\
\hline & & Emina & 10 & $9,1 \%$ \\
\hline & & Pixy & 6 & $5,5 \%$ \\
\hline & & Lakme & 1 & $0,9 \%$ \\
\hline & & Maybelline & 1 & $0,9 \%$ \\
\hline & & Oriflame & 1 & $0,9 \%$ \\
\hline & & Roro Mendut & 1 & $0,9 \%$ \\
\hline \multicolumn{3}{|c|}{ Jumlah } & 110 & $100 \%$ \\
\hline \multirow{5}{*}{3} & \multirow{5}{*}{ Pekerjaan } & Pelajar/mahasiswa & 77 & $70 \%$ \\
\hline & & Karyawan & 20 & $18,2 \%$ \\
\hline & & PNS/TNI/POLRI & 0 & $0 \%$ \\
\hline & & Wiraswasta & 4 & $3,6 \%$ \\
\hline & & Lainnya, & 9 & $8,2 \%$ \\
\hline \multicolumn{3}{|c|}{ Jumlah } & 110 & $100 \%$ \\
\hline \multirow{4}{*}{4} & \multirow{4}{*}{$\begin{array}{l}\text { Pendapatan per } \\
\text { bulan }\end{array}$} & $<\mathrm{Rp} 1.500 .000$ & 89 & $80,9 \%$ \\
\hline & & $\begin{array}{l}\mathrm{Rp} 1.500 .000-\mathrm{Rp} \\
2.400 .000\end{array}$ & 17 & $15,5 \%$ \\
\hline & & $\begin{array}{l}\mathrm{Rp} 2.500 .000-\mathrm{Rp} \\
3.500 .000\end{array}$ & 3 & $2,7 \%$ \\
\hline & & $>\operatorname{Rp} 3.500 .000$ & 1 & $0,9 \%$ \\
\hline \multicolumn{3}{|c|}{ Jumlah } & 110 & $100 \%$ \\
\hline
\end{tabular}

Sumber : Hasil Penelitian dan Pembahasan, 2020.

\section{HASIL DAN PEMBAHASAN \\ Uji Validitas}

Diketahui dalam penelitian ini jumlah responden sebanyak 110 maka $r$ tabel dapat diperoleh melalui tabel $\mathrm{r}$ product moment pearson dengan $\mathrm{df}$ (degree of freedom $)=\mathrm{n}-2$, jadi $\mathrm{df}=110-2=108$, maka dapat diketahui $\mathrm{r}$ tabel $=0,1576$. Butir pernyataan dikatakan valid jika $r$ hitung $\geq r$ tabel. Dari tabel 2 berikut, dapat disimpulkan masing-masing variabel dinyatakan valid atau lebih besar dari $\mathrm{r}$ tabel $(0,1576)$. Hal tersebut dapat dilihat dari Corrected Item Total Correlation. Analisis output bisa dilihat pada tabel 2 sebagai berikut : 
Tabel 2. Hasil Uji Validitas

\begin{tabular}{clcc}
\hline No & \multicolumn{1}{c}{ Variabel } & r tabel & Keterangan \\
\hline 1 & Sikap Konsumen & 0,1576 & Valid \\
2 & Persepsi Harga & 0,1576 & Valid \\
3 & Persepsi Risiko & 0,1576 & Valid \\
\hline
\end{tabular}

Sumber : Hasil Penelitian dan Pembahasan, 2020.

\section{Uji Reliabilitas}

Suatu variabel dikatakan reliabel jika memiliki nilai cronbach alpha $>0,60$. Dari tabel berikut, hasil uji reliabilitas menunjukan nilai koefisien alpha $>0,60$ artinya pernyataan dalam kuesioner tersebut dianggap reliable. Analisis output bisa dilihat pada tabel 3 sebagai berikut :

Tabel 3. Hasil Uji Reliabilitas

\begin{tabular}{llccccc}
\hline No & \multicolumn{1}{c}{ Variabel } & Item & \multicolumn{2}{c}{ Reliabilitas } & N & Keterangan \\
& & & Cronbach Alpha & Standar & Of Items & \\
\cline { 3 - 5 } 1 & Keputusan Pembelian & $\mathrm{Y}$ & 0,837 & 0.60 & 8 & Reliable \\
2 & Sikap Konsumen & $\mathrm{X}_{1}$ & 0,748 & 0.60 & 3 & Re liable \\
3 & Persepsi Harga & $\mathrm{X}_{2}$ & 0,761 & 0.60 & 5 & Reliable \\
4 & Persepsi Risiko & $\mathrm{X}_{3}$ & 0,877 & 0.60 & 6 & Reliable \\
\hline
\end{tabular}

Sumber : Hasil Penelitian dan Pembahasan, 2020.

\section{Uji Normalitas}

Dalam penelitian ini, peneliti menggunakan analisis Kolmogorov-Smirnov (K-S). Nilai residual terstandarisasi berdistribusi normal jika nilai sig. $>\alpha(a l p h a)$. Berdasarkan tabel 4 berikut, diketahui bahwa hasil perhitungan nilai asymptotic sig. menunjukkan nilai sebesar 0.086 dapat disimpulkan bahwa data unstandardized residual telah terdistribusi normal, karena nilai tersebut lebih besar dari 0,05. Analisis output bisa dilihat pada tabel 4 sebagai berikut :

Tabel 4. Hasil Uji Normalitas

One-Sample Kolmogorov-Smirnov Test

\begin{tabular}{|ll|r|}
\hline & & $\begin{array}{c}\text { Unstandardized } \\
\text { Residual }\end{array}$ \\
\hline $\mathrm{N}$ & Mean & 110 \\
Normal Parameters & $\mathrm{a}$, &, 0000000 \\
& Std. Deviation &, 36685412 \\
Most Extreme Differences & Absolute &, 079 \\
& Positive &, 043 \\
& Negative &,- 079 \\
Test Statistic & &, 079 \\
Asymp. Sig. (2-tailed) & &, $086^{c}$ \\
\hline
\end{tabular}

a. Test distribution is Normal. 


\author{
b. Calculated from data. \\ c. Lilliefors Significance Correction. \\ Sumber : Hasil Penelitian dan Pembahasan, 2020.
}

\title{
Uji Multikolinearitas
}

Berdasarkan tabel 5 berikut, diketahui bahwa hasil perhitungan nilai tolerance menunjukkan tidak ada variabel independen yang memiliki nilai tolerance $\geq 0,10$ yang berarti tidak ada korelasi antar variabel independen. Sedangkan hasil perhitungan VIF juga menunjukkan tidak ada satu variabel independen yang memiliki nilai $\leq 10$. Jadi dapat disimpulkan bahwa tidak ada multikolinearitas antar variabel dependen dalam model regresi penelitian ini. Analisis output bisa dilihat pada tabel 5 sebagai berikut :

Tabel 5. Hasil Uji Multikolinearitas

\begin{tabular}{clccc}
\hline No. & Variabel & Tolerance & VIF & Keterangan \\
1 & Sikap Konsumen & 0,615 & 1,626 & Non Multikolinearitas \\
2 & Persepsi Harga & 0,500 & 1,998 & Non Multikolinearitas \\
3 & Persepsi Risiko & 0,495 & 2,019 & Non Multikolinearitas \\
\hline
\end{tabular}

Sumber : Hasil Penelitian dan Pembahasan, 2020.

\section{Uji Heteroskedastisitas}

Berdasarkan tabel 6 berikut, diketahui bahwa hasil perhitungan menunjukkan tidak ada variabel independen yang memiliki nilai sig. kurang dari 0,05 yang berarti tidak ada heteroskedastisitas antar variabel dalam model regresi penelitian ini. Analisis output bisa dilihat pada tabel 6 sebagai berikut :

Tabel 6. Hasil Uji Heteroskedastisitas

\begin{tabular}{|c|c|c|c|c|c|c|}
\hline \multicolumn{7}{|c|}{ Coefficients $^{\mathrm{a}}$} \\
\hline \multirow{2}{*}{\multicolumn{2}{|c|}{ Model }} & \multicolumn{2}{|c|}{ Unstandardized Coefficients } & $\begin{array}{l}\text { Standardized } \\
\text { Coefficients }\end{array}$ & \multirow[b]{2}{*}{$\mathrm{T}$} & \multirow[b]{2}{*}{ Sig. } \\
\hline & & $\mathrm{B}$ & Std. Error & Beta & & \\
\hline 1 & (Constant) & $-6,587$ & 2,772 & & $-2,377$ & ,019 \\
\hline & LnSikapKonsumen & 3,720 & 2,236 & 197 & 1,664 & 099 \\
\hline & LnPersepsiHarga & 1,836 & 2,138 &, 111 & ,859 & ,392 \\
\hline & LnPersepsiRisiko & $-3,415$ & 1,901 &,- 238 & $-1,796$ & 075 \\
\hline
\end{tabular}

a. Dependent Variable: LnU2

Sumber : Hasil Penelitian dan Pembahasan, 2020. 


\section{Uji Regresi Berganda}

Analisis output uji regresi berganda bisa dilihat pada tabel 7 sebagai berikut :

Tabel 7. Hasil analisis regresi linear berganda

\begin{tabular}{|c|c|c|c|c|c|c|}
\hline \multicolumn{7}{|c|}{ Coefficients $^{\mathrm{a}}$} \\
\hline \multirow{2}{*}{\multicolumn{2}{|c|}{ Model }} & \multicolumn{2}{|c|}{ Unstandardized Coefficients } & $\begin{array}{l}\text { Standardized } \\
\text { Coefficients }\end{array}$ & \multirow[b]{2}{*}{$\mathrm{T}$} & \multirow[b]{2}{*}{ Sig. } \\
\hline & & $\mathrm{B}$ & Std. Error & Beta & & \\
\hline & (Constant) & 1,509 & ,347 & & 4,344 &, 000 \\
\hline & Sikap_Konsumen &,- 214 & ,096 &,- 195 & $-2,239$ & ,027 \\
\hline & Persepsi_Harga & ,317 & ,099 & ,309 & 3,206 & ,002 \\
\hline & Persepsi_Risiko &, 523 &, 088 &, 576 & 5,951 &, 000 \\
\hline
\end{tabular}

a. Dependent Variable: Keputusan_Pembelian

Sumber : Hasil Penelitian dan Pembahasan, 2020.

Berdasarkan tabel 9 diatas, dapat disusun persamaan regresi sebagai berikut :

$$
\begin{aligned}
& \mathbf{Y}=\mathbf{a}+\boldsymbol{\beta}_{\mathbf{1}} \mathbf{X}_{\mathbf{1}}+\boldsymbol{\beta}_{\mathbf{2}} \mathbf{X}_{\mathbf{2}}+\boldsymbol{\beta}_{\mathbf{3}} \mathbf{X}_{\mathbf{3}}+\mathbf{e} \\
& \mathbf{Y}=1,509-0,214 \mathbf{X}_{1}+0,317 \mathbf{X}_{2}+0,523 \mathbf{X}_{3}
\end{aligned}
$$

Adapun interpretasi dari persamaan regresi tersebut adalah :

$\alpha=$ Nilai konstanta $(\alpha)$ menunjukan nilai sebesar 1,509 menyatakan bahwa Sikap Konsumen, Persepsi Harga dan Persepsi Risiko bernilai nol atau tidak ada perubahan, maka keputusan pembelian sebesar 1,509 satuan

$\beta_{1}=-0,214$. Nilai koefisien regresi variabel sikap konsumen menunjukan nilai negatif sebesar -0,214 yang berarti bahwa setiap peningkatan sikap konsumen sebesar 1 satuan maka menyebabkan keputusan pembelian konsumen menurun sebesar 0,214 satuan dengan asumsi variabel lain tetap.

$\beta_{2}=0,317$. Nilai koefisien regresi variabel Persepsi Harga menunjukan nilai positif sebesar 0,317 yang berarti bahwa setiap peningkatan Persepsi Harga sebesar 1 satuan maka menyebabkan keputusan pembelian konsumen meningkat sebesar 0,317 satuan dengan asumsi variabel lain tetap.

$\beta_{3}=0,523$. Nilai koefisien regresi variabel Persepsi Risiko menunjukan nilai positif sebesar 0,523 yang berarti bahwa setiap peningkatan Persepsi Risiko sebesar 1 satuan maka menyebabkan keputusan pembelian konsumen meningkat sebesar 0,523 satuan dengan asumsi variabel lain tetap.

Berdasarkan hasil analisis regresi linear berganda diatas, maka variabel yang paling berpengaruh terhadap keputusan pembelian kosmetik berlabel halal yaitu persepsi risiko. selain variabel persepsi risiko, variabel lain juga mempengaruhi keputusan pembelian kosmetik berlabel halal yaitu sikap konsumen dan persepsi harga. 


\section{Uji Koefisien Determinasi}

berikut :

Analisis output uji koefisien determinasi $\left(\mathrm{R}^{2}\right)$ dapat dilihat dalam tabel 8 sebagai

Tabel 8. Hasil Uji Koefisien Determinasi

\begin{tabular}{|l|c|r|r|r|}
\hline Model & R & R Square & $\begin{array}{c}\text { Adjusted R } \\
\text { Square }\end{array}$ & $\begin{array}{c}\text { Std. Error of } \\
\text { the Estimate }\end{array}$ \\
\hline 1 &, $713^{\mathrm{a}}$ &, 508 &, 494 &, 37201 \\
\hline
\end{tabular}

a. Predictors: (Constant), Persepsi_Risiko, Sikap_Konsumen,

Persepsi_Harga

b. Dependent Variable: Keputusan_Pembelian

Sumber : Hasil Penelitian dan Pembahasan, 2020.

Berdasarkan tabel 8 diatas, maka dapat disimpulkan sebagai berikut :

1. Besarnya nilai koefisien korelasi $\mathrm{R}$ adalah 0.713 , nilai tersebut menunjukkan bahwa besarnya

pengaruh variabel independen terhadap variabel dependen kuat.

2. Koefisien determinasi $\left(R^{2}\right)$ sebesar 0.494 , yang artinya sebanyak $49,4 \%$ variabel independen sikap konsumen, persepsi harga dan persepsi risiko mempengaruhi keputusan pembelian, sedangkan sisanya 50,6\% dipengaruhi oleh faktor-faktor lain yang tidak diteliti dalam penelitian ini.

3. Standart error (e) sebesar 0,37201dibulatkan menjadi 0.372 yang artinya dalam persamaan regresi besarnya adalah $0.372 \mathrm{x}$ t tabel (1.659) sehingga dalam persamaan regresi, besar standart error sebesar 0,617.

Uji Simultan (F test)

Untuk menyimpulkan apakah model masuk dalam kategori cocok (fit) atau tidak, harus membandingkan nilai $\mathrm{f}$ hitung dan nilai $\mathrm{f}$ tabel dengan $\mathrm{df}: \alpha,(\mathrm{k}-1),(\mathrm{n}-\mathrm{k})$, dimana $\mathrm{df}$ : $0.05,(4-1),(110-4)$ diperoleh besarnya nilai f tabel sebesar 2.69. Berikut ini merupakan hasil pengujian Simultan (F test) yang dapat dilihat pada tabel 9 sebagai berikut :

Tabel 9. Tabel Uji F (Simultan)

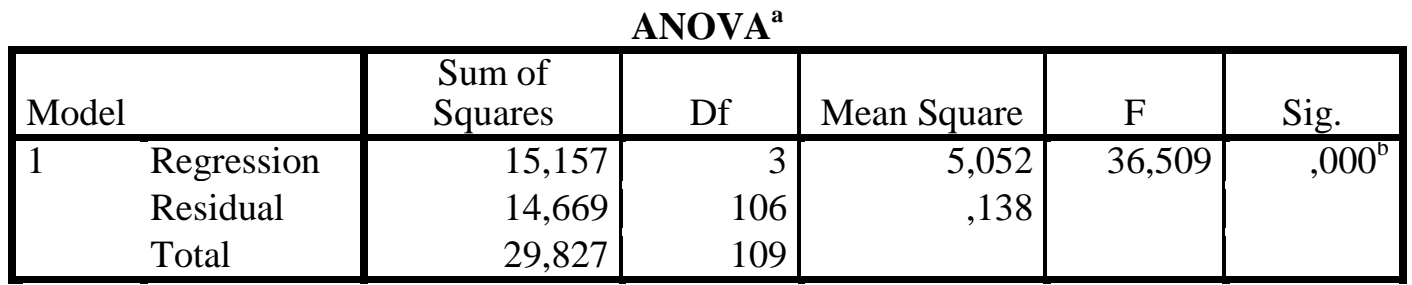

a. Dependent Variable: Keputusan_Pembelian

b. Predictors: (Constant), Persepsi_Risiko, Sikap_Konsumen, Persepsi_Harga

Sumber : Hasil Penelitian dan Pembahasan, 2020.

Berdasarkan tabel 9 diatas, dapat diketahui besarnya nilai $\mathrm{f}$ hitung adalah sebesar 36.509 sedangkan nilai $\mathrm{f}$ tabel sebesar 2.69 sehingga dapat diketahui $\mathrm{f}$ hitung $>\mathrm{f}$ tabel yaitu $36.509>2.69$ serta nilai signifikan sebesar 0.000 dengan demikian variabel sikap konsumen, persepsi harga dan persepsi risiko secara bersama-sama berpengaruh signifikan terhadap keputusan pembelian diterima. Adapun gambar kurva penerimaan hipotesisnya dapat dilihat pada gambar 2 sebagai berikut : 


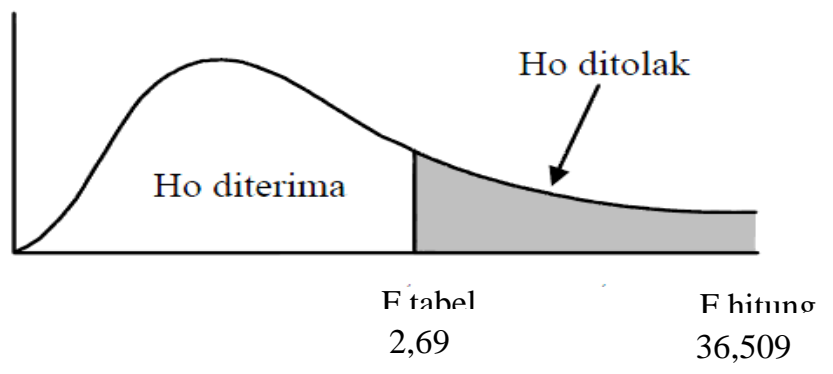

Gambar 2. Kurva Hipotesis Uji F

Sumber : Hasil Penelitian dan Pembahasan, 2020.

\section{Uji Parsial (t test)}

Berikut ini merupakan hasil pengujian hipotesis yang dapat dilihat pada tabel 7 sebagai berikut :

1. Hipotesis kedua

Berdasarkan hasil uji t untuk variabel sikap konsumen $\left(X_{1}\right)$ diperoleh nilai $t_{\text {hitung }}-2,239$ dan $\mathrm{t}_{\text {tabel }}$ sebesar 1,65922. Hal ini berarti $\mathrm{t}_{\text {hitung }}<\mathrm{t}_{\text {tabel }}$ sedangkan signifikansi 0,027 oleh karena nilai $-t_{\text {hitung }}<t_{\text {tabel }}(-2,239)<1,65922$ artinya secara parsial terdapat pengaruh negatif signifikan antara sikap konsumen dengan keputusan pembelian. Hipotesis Ditolak.

Adapun gambar kurva penerimaan hipotesis kedua dapat dilhat pada gambar 3 sebagai berikut :

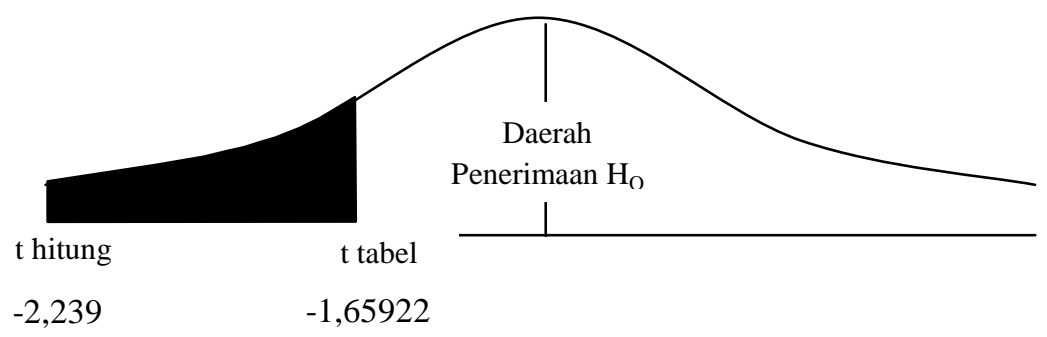

Gambar 3. Kurva Uji Penerimaan Hipotesis kedua

Sumber : Hasil Penelitian dan Pembahasan, 2020.

2. Hipotesis Ketiga

Berdasarkan hasil uji t untuk variabel persepsi harga $\left(\mathrm{X}_{2}\right)$ diperoleh nilai $\mathrm{t}_{\text {hitung }} 3,206$ dan $t_{\text {tabel }}$ sebesar 1,65922. Hal ini berarti $t_{\text {hitung }}>t_{\text {tabel }}$ sedangkan signifikansi 0,002 oleh karena nilai $t_{\text {hitung }}>t_{\text {tabel }}(3,206>1,65922)$ artinya secara parsial terdapat pengaruh positif signifikan antara persepsi harga dengan keputusan pembelian. Hipotesis Diterima.

Adapun gambar kurva penerimaan hipotesis kedua dapat dilhat pada gambar 4 sebagai berikut : 




Gambar 4. Kurva Uji Penerimaan Hipotesis Ketiga

Sumber : Hasil Penelitian dan Pembahasan, 2020.

3. Hipotesis Keempat

Berdasarkan hasil uji t untuk variabel kualitas produk $\left(\mathrm{X}_{3}\right)$ diperoleh nilai $\mathrm{t}_{\text {hitung }} 5,951$ (tabel 4.11) dan $t_{\text {tabel }}$ sebesar 1,65922 (lampiran 10). Hal ini berarti $t_{\text {hitung }}>t_{\text {tabel }}$ sedangkan signifikansi 0,000 oleh karena nilai $t_{\text {hitung }}>t_{\text {tabel }}(5,951>1,65922)$ artinya secara parsial terdapat pengaruh positif signifikan antara persepsi risiko dengan keputusan pembelian. Hipotesis Diterima.

Adapun gambar kurva penerimaan hipotesisnya dapat dilihat pada gambar 5 sebagai berikut :

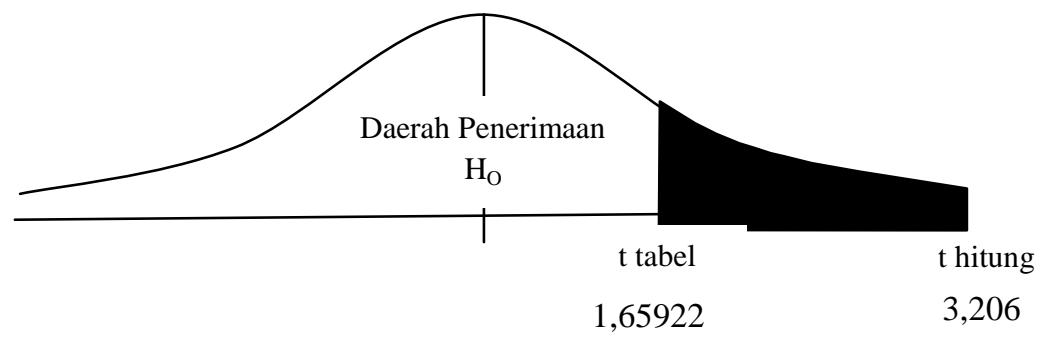

Gambar 5. Kurva Uji Penerimaan Hipotesis Keempat

Sumber : Hasil Penelitian dan Pembahasan, 2020.

\section{PEMBAHASAN}

1. Hasil hipotesis pertama menyatakan bahwa sikap konsumen, persepsi harga dan persepsi risiko berpengaruh secara simultan terhadap keputusan pembelian kosmetik berlabel halal, sehingga $\mathbf{H 1}$ diterima. Hasil ini menunjukan bahwa jika perusahaan mampu mengidentifikasi kebutuhan konsumen dengan baik, sehingga konsumen menunjukan sikap suka pada produknya, menetapkan harga yang tepat, meminimalkan risiko yang akan didapat konsumen, sehingga membuat meningkatnya keputusan pembelian konsumen. Maka produk-produk perusahaan tersebut akan mampu terjual dan bersaing di pasar. 
Hal ini selaras dengan penelitian dari (Arifin dan Khasanah, 2017) dan (Rahmadi dan Malik, 2016) yang menyatakan bahwa sikap konsumen, persepsi harga dan persepsi risiko secara simultan berpengaruh signifikan terhadap keputusan pembelian.

2. Hasil hipotesis kedua menyatakan bahwa sikap konsumen berpengaruh negatif signifikan terhadap keputusan pembelian kosmetik berlabel halal, sehingga $\mathbf{H 2}$ ditolak. Sikap ini dilakukan konsumen berdasarkan pandangan terhadap produk dan proses belajar baik dari pengalaman ataupun yang lain. Sikap konsumen bisa merupakan sikap positif maupun negatif terhadap produk tertentu. Sikap penting bagi konsumen karena pengetahuan akan mempengaruhi keputusan pembelian (Marchall dkk, 2015). Artinya bahwa semakin tinggi sikap negatif konsumen maka keputusan pembelian konsumen akan semakin berkurang. Hal ini selaras dengan penelitian yang dilakukan oleh (Marchall dkk, 2015) yang menyatakan bahwa sikap konsumen berpengaruh negatif terhadap keputusan pembelian.

3. Hasil hipotesis ketiga menyatakan bahwa persepsi harga berpengaruh positif signifikan terhadap keputusan pembelian kosmetik berlabel halal, sehingga $\mathbf{H 3}$ diterima. Persepsi harga adalah cara pandang konsumen dalam menilai apakah sebuah produk mempunyai harga yang wajar, mahal atau murah (Budiyanto, 2018). Artinya konsumen dalam melakukan keputusan pembelian akan mempertimbangkan harga produk, keterjangkauan harga dan kesesuaian harga dengan anggaran yng dimilki konsumen.

Hal ini selaras dengan penelitian yang dilakukan oleh Arifin dan Khasanah (2017) yang menyatakan bahwa persepsi harga berpengaruh positif signifikan terhadap keputusan pembelian.

4. Hasil hipotesis ketiga menyatakan bahwa persepsi risiko berpengaruh positif signifikan terhadap keputusan pembelian kosmetik berlabel halal, sehingga $\mathbf{H 4}$ diterima. Persepsi risiko adalah ketidakpastian yang dihadapi para konsumen jika mereka tidak dapat meramalkan konsekuensi keputusan pembelian mereka. Artinya jika persepsi risiko rendah maka akan meningkatkan keputusan pembelian.

Hal ini selaras dengan penelitian yang dilakukan oleh Anandita dan Saputra (2015) yang menunjukan bahwa persepsi risiko berpengaruh positif signifikan terhadap keputusan pembelian.

\section{KESIMPULAN DAN SARAN \\ Kesimpulan}

Berdasarkan hasil analisis pada penelitian ini, maka dapat disimpulkan hal-hal sebagai berikut :

1. Sikap konsumen (X1), persepsi harga (X2) dan persepsi risiko (X3) secara simultan berpengaruh signifikan terhadap keputusan pembelian (Y) kosmetik berlabel halal.

2. Sikap konsumen (X1) secara parsial berpengaruh negatif signifikan terhadap keputusan pembelian (Y) kosmetik berlabel halal.

3. Persepsi harga (X2) secara parsial berpengaruh positif signifikan terhadap keputusan pembelian (Y) kosmetik berlabel halal.

4. Persepsi risiko (X3) secara parsial berpengaruh positif signifikan terhadap keputusan pembelian (Y) kosmetik berlabel halal.

\section{Saran}

Berdasarkan hasil kesimpulan dari penelitian yang diperoleh, beberapa saran dapat dirumuskan antara lain sebagai berikut :

\section{Bagi Konsumen}


a. Sebelum mengambil keputusan pembelian suatu produk hendaknya konsumen mengevaluasi dan mencari informasi kepada keluarga, teman dan rekan sehingga bisa memilih produk yang baik.

b. Sebaiknya sebelum melakukan pembelian hendaknya konsumen mempertimbangkan kehalalan suatu produk.

c. Sebaiknya pada saat akan membeli konsumen mempertimbangkan harga, apakah harga tersebut murah atau mahal dan dalam penetapan harganya sudah sesuai dengan kualitas produk.

d. Sebaiknya pada saat akan membeli sutau produk hendaknya konsumen melihat label pada kemasan produk tersebut halal dan tidak membuat ketergantungan.

\section{Bagi Perusahaan}

a. Berdasarkan penelitian diatas untuk keputusan pembelian dimana terdapat indikator terendah dengan nilai rata-rata 3,58 dengan skor 3 (netral), yaitu indikator saya menggunakan kosmetik berlabel halal karena rekomendasi atau ajakan dari informasi keluarga, teman dan rekan sehingga saya membeli. Sebaiknya perusahaan meningkatkan pemasaran dan promosi agar konsumen semakin tertarik membeli dan menggunakan produk kosmetik berlabel halal.

b. Berdasarkan penelitian diatas untuk sikap konsumen dimana terdapat indikator terendah dengan nilai rata-rata 4,33 dengan skor 4 (setuju), yaitu indikator saya sering membeli dan menggunakan produk kosmetik berlabel halal. Sebaiknya perusahaan meningkatkan inovasi, kualitas dan citra merek kosmetik berlabel halal sehingga konsumen menjadi loyal dan melakukan pembelian ulang terhadap kosmetik berlabel halal.

c. Berdasarkan penelitian diatas untuk persepsi harga dimana terdapat indikator terendah dengan nilai rata-rata 3,82 dengan skor 3 (netral), yaitu indikator saya membeli kosmetik berlabel halal karena harganya terjangkau. Sebaiknya perusahaan memeperhatikan kualitas, harga yang terjangkau dan persaingan dengan perusahaan lainnya.

d. Berdasarkan penelitian diatas untuk persepsi risiko dimana terdapat indikator terendah dengan nilai rata-rata 3,75 dengan skor 3 (netral), yaitu indikator kosmetik berlabel halal bisa digunakan dalam jangka waktu yang lama. Sebaiknya perusahaan memperhatikan kualitas dan meyakinkan konsumen bahwa produk yang mereka pakai dapat digunakan dengan aman dan tidak membuat ketergantungan.

\section{Bagi Peneliti Selanjutnya}

a. Peneliti selanjutnya dimungkinkan untuk menambah variabel independen lain, karena masih banyak faktor lain yang dapat mempengaruhi keputusan pembelian. Misalnya kualitas produk, iklan yang diduga dapat mempengaruhi keputusan pembelian.

b. Penelitian selanjutnya hendaknya mengambil sampel bukan hanya yang berjenis kelamin wanita, akan lebih baik jika sampel yang di ambil keseluruhan konsumen kosmetik berlabel halal.

c. Peneliti selanjutnya hendaknya tidak hanya meneliti kosmetik berlabel halal namun bisa meneliti makanan, karena konsumen sangat peduli terhadap kehalalan yang akan mereka konsumsi khususnya makanan sehari-hari.

\section{Keterbatasan dalam penelitian}

Keterbatasan dalam penelitian ini secara khusus diperoleh sebagai berikut : 
1. Dalam penelitian ini hanya meneliti sikap konsumen, persepsi harga dan persepsi risiko, berdasarkan koefisien determinasi menunjukan nilai Adjust $R$-Square sebesar 49,4,\%, sisanya dipengaruhi oleh variabel lain. Sedangkan masih banyak faktor lain yang mempengaruhi keputusan pembelian.

2. Penelitian ini hanya mengambil sampel konsumen wanita yang menggunakan kosmetik berlabel halal, akan lebih baik jika sampel yang diambil meliputi seluruh konsumen.

3. Adanya keterbatasan penelitian ini dengan menggunakan metode kuesioner yaitu terkadang jawaban yang diberikan oleh sampel/responden tidak menunjukan keadaan yang sebenarnya.

\section{DAFTAR PUSTAKA}

Anandita, Florentinus., Bigar Anung, Sumarno Dwi Saputra. 2015. Analisis Pengaruh Kepercayaan, Keamanan, Kualitas Pelayanan dan Persepsi akan Risiko terhadap Keputusan Pembelian Melalui Situs Jejaring Sosial. Jurnal Ekonomi dan Kewirausahaan Vol. 15 No. 2 Juni 2015

Arifin., Kholifatul Khoiriyah. 2018. Pengaruh Trust dan Risiko terhadap Keputusan Pembelian di Situs Jual Beli Online. Jurnal Ilmiah Ekonomi Manajemen Vol. 9 No. 1 Juli 2018

Arifin, Muhammad., Imroatul Khasanah. 2017. Analisis Pengaruh Kualitas Produk, Persepsi Harga dan Sikap Terhadap Keputusan Pembelian. Diponegoro Journal Of Management Vol. 6 No. 42017

Ariyanti, Kurnia., Sri Setyo Iriani. 2014. Pengaruh Persepsi Nilai dan Persepsi Risiko terhadap Niat Beli Kosmetik Organik. Jurnal Ilmu Manajemen Vol. 2 No. 4 Oktober 2014

Aspan, Henry., Iskandar Muda Sipayung, Ade Putri Muharrami, Husni Muharram Ritonga. 2017. The Effect of Halal Label, Halal Awarness, Product Price and Brand Image to the Purchasing Decision on Cosmetic Products. International Journal of Global Sustainability Vol. 1 No. 12017

Astuti, Retno., Rizky Lutfian Ramadhan Silalahi, Galuh Dian Paramita Wijaya. 2015. Marketing Strategy Based On Marketing Mix Influence On Purchasing Decisions Of Malang Apples Consumers at Giant Olympic Garden Mall (MOG), Malang City, East Java Province, Indonesia. Agriculture and Agricultural Science Procedia Vol. 32015

Budiyanto, Arief. 2018. Pengaruh Persepsi Harga, Kualitas Layanan Dan Brand Image Terhadap Tingkat Kepuasan Konsumen Di PT. Yerry Primatama Hosindo. Jurnal Pemasaran Kompetitif Vol. 1 No. 3 April 2018

Cahyani, Sri, Nidia., S.L.H.V Joyce Lapian, Johan Tumiwa. 2017. The Effect Of Brand Image, Perceived Price And Perceived Quality On Consumers Decision Of Pond's Skin Care Product. Jurnal EMBA Vol. 5 No. 2 Juni 2017

Ghozali, Imam. 2016. Analisis Multivariete Dengan Program IBM SPSS 23. Edisi 8. Badan Penerbit Universitas Diponegoro. Semarang

Gunawan, Steffi. 2015. The Impact of Motivation, Perception and Attitude toward Consumer Purchasing Decision. Jurnal iBuss Management Vol. 3 No. 22015 
Haro, Andrian. 2018. Determinants Of Halal Cosmetics Purchase Intention On Indonesian Female Muslim Customer. Journal Of Entrepreneurship, Business and Economics Vol. 6 No. 12018.

Indarti. 2010. Analisis Faktor-Faktor yang Dipertimbangkan Konsumen Kosmetik dalam Keputusan Pembelian Produk Pemutih Wajah. Jurnal WACANA Vol. 13 No. 4 Oktober 2010

Jamaludin, Achmad., Zainul Arifin, Kadarismasn Hidayat. 2015. Pengaruh Promosi Online dan Persepsi Harga terhadap Keputusan Pembelian. Jurnal Administrasi Bisnis Vol. 21 No. 1 April 2015

Kotler, Philip., Kevin Lane Keller. 2009. Marketing Management. Edisi 13 Jilid 1. Erlangga. Jakarta

Kotler, Philip., Kevin Lane Keller. 2009. Marketing Management. Edisi 13 Jilid 2. Erlangga. Jakarta

Marchall, Maikell., Lisbeth Mananeke, Ferdy Roring. 2015. Pengaruh Brand Equity, Store Atmosphere dan Sikap Konsumen Terhadap Keputusan Pembelian Pakaian Fashionable pada 3 second Manado Town Square. Jurnal EMBA Vol. 3 No. 1 Maret 2015

Puspitasari, Ratih Hesty Utami. 2019. Analisis Pengaruh Keputusan Pembelian pada Kosmetik Berlabel Halal. Jurnal Bussiness Management Analysis Vol. 2 No. 1 April 2019

Rahmadi, Heksawan., Deni Malik. 2016. Pengaruh Kepercayaan dan Persepsi Risiko Terhadap Keputusan Pembelian E-Commerce. Jurnal Ilmiah Untuk Mewujudkan Masyarakat Madani Vol. 3 No. 1 Maret 2016

Rommy, Nusrai Bnu Hajar Hatuti Moh. Amin Sinarwaty Nursaban., Abdul Razak Yusuf Nofal Nur. Effect Of Brand Image And Price Perception On Purchase Decision. IOSR Journal Of Business and Management Vol. 20 No. 8 Agustus 2018

Samosir, Charlie Bernando Halomoan., Arief Bowo Prayoga K. 2015. Jurnal Pengaruh Persepsi Harga dan Promosi Terhadap Keputusan Pembelian Konsumen Produk Enervon-C. Jurnal Ilmiah Manajemen dan Bisnis Vol. 1 No. 3 November 2015

Sangadji., Sopiah. 2013. Perilaku Konsumen. Andi. Yogyakarta

Sari, Fenti Mayang., Andi Makhrian, Khairil Buldani. 2018. Pengaruh Label Halal dan Harga Terhadap Keputusan Membeli Poduk Kosmetik Wardah. Jurnal Professional GIS UNIVED Vol. 5 No 1 Juni 2018

Setyarko, Yugi. 2016. Analisis Persepsi Harga, Promosi, Kualitas Layanan Dan Kemudahan Penggunaan Terhadap Keputusan Pembelian Produk Secara Online. Jurnal Ekonometrika dan Manajemen Vol. 5 No. 2 Oktober 2016

Sugiyono. 2016. Metode Penelitian Kuantitatif, Kualitatif dan R\&D. ALFABETA. Bandung

Suhir, Moch., Imam Suyadi, Riyadi. 2014. Pengaruh Persepsi Risiko, Kemudahan dan Manfaat terhadap Keputusan Pembelian Secara Online. Jurnal Administrasi Bisnis Vol. 8 No. 1 Februari 2014

Sujarweni, V.Wiratna. 2015. Metodologi Penelitian Bisnis \& Ekonomi. Pustaka Baru Press. Yogyakarta

Suliyanto. 2011. Ekonometrika Terapan. Andi. Yogyakarta

Suliyanto. 2018. Metode Penelitian Bisnis. Andi. Yogyakarta 
Tarigan, Eka Dewi Setia. 2016. Pengaruh Gaya Hidup, Label Halal dan Harga Terhadap Keputusan Pembelian Kosmetik Wardah. Jurnal Konsep Bisnis dan Manajemen Vol. 3 No. 1 November 2016

Usvita, Mega. 2013. Pengaruh Iklan dan Sikap Konsumen Terhadap Keputusan Pembelian Cream Wajah Pond's. Jurnal Apresiasi Ekonomi Vol. 1 No. 1 Januari 2013

Widiastuti, Karolina., Sunarti. 2017. Pengaruh Persepsi Risiko, Kualitas, Harga Dan Nilai Konsumen Wanita Muslim Terhadap Citra Merek Kosmetik Berlabel Halal. Jurnal Administrasi Bisnis Vol. 51 No. 1 Oktober 2017

Zulfa, Latifah., Retno Hidayat. 2018. Analisis Pengaruh Persepsi Risiko, Kualitas Situs Web dan Kepercayaan Konsumen terhadap Keputusan Pembelian Konsumen ECommerce Shopee di kota Semarang. Diponegoro Journal of Management Vol. 7 No. 32018

https://kemenperin.go.id/artikel/19435/Kinerja-Industri-Kosmetik-Nasional-LampauiPertumbuhan-Ekonomi www.m.antaranews.com [Accessed 23 Oktober 2019]

https://swa.co.id/swa/trends/economic-issues/kemenperin-genjot-kosmetik-dan-obattradisional-jadi-andalan-ekspor [Accessed 23 Oktober 2019]

https://m.cnnindonesia.com/gaya-hidup/20180329232035-277-287005/mengenal-ketentuankosmetik-berlabel-halal-dari-lppom-mui [Accessed 25 Oktober 2019]

https://www.halalmuibali.or.id/pengertian-halal-dan-haram-menurut-ajaran-islam [Accessed 25 Oktober 2019]

https://www.google.com/amp/s/m.antaranews.com/amp/berita/987632/bpom-sebut-50persen-izin-edar-adalah-kosmetik [Accessed 25 Oktober 2019]

https://m.kumparan.com/amp/kumparanstyle/daftar-kosmetik-halal-di-indonesia-yang-telahdisertifikasi-mui-1548333618812262658 [Accessed 20 November 2019]

https://m.liputan6.com/bisnis/read/3866592/sektor-industri-yang-bakal-tumbuh-tinggi-di2019 [Accessed 26 November 2019]

https://www.google.com/amp/s/m/m.antaranews.com/amp/berita/954315/adu-kreatifindustri-kosmetik-nasional-dengan-produk-impor [Accessed 26 November 2019$]$ https://www.halalmuibali.or.id/kosmetika-kepalsuan [Accessed 31 januari 2020] 